\title{
Driving Factors for Torrential Mass-Movements Occurrence in the Western Alps
}

\author{
Davide Tiranti ${ }^{1,2 *}$, Roberto Cremonini ${ }^{1}$, Irene Asprea ${ }^{2}$ and Federica Marco ${ }^{3}$ \\ ${ }^{1}$ Department of Forecasting Systems, Regional Agency for Environmental Protection of Piemonte, Turin, Italy, ${ }^{2}$ Department of \\ Earth Sciences, University of Turin, Turin, Italy, ${ }^{3}$ Department of Geology and Geohazards, Regional Agency for Environmental \\ Protection of Piemonte, Turin, Italy
}

OPEN ACCESS

Edited by:

Gary E. Stinchcomb, Murray State University, USA

Reviewed by: Yingkui Li,

University of Tennessee, USA David R. Butler,

Texas State University, USA

${ }^{*}$ Correspondence: Davide Tirant davide.tiranti@arpa.piemonte.it

Specialty section

This article was submitted to Quaternary Science, Geomorphology and Paleoenvironment, a section of the journal Frontiers in Earth Science

Received: 19 November 2015 Accepted: 08 February 2016 Published: 24 February 2016

Citation:

Tiranti D, Cremonini R, Asprea I and Marco $F$ (2016) Driving Factors for Torrential Mass-Movements Occurrence in the Western Alps. Front. Earth Sci. 4:16 doi: 10.3389/feart.2016.00016
To understand the behavior of torrential processes in the alpine environment, the conditions mainly responsible for the occurrence of these phenomena have to be identified and distinguished as predisposing and triggering factors. In this regard, this study is aimed to understanding which factors lead to the occurrence of a given torrential processes in alpine catchments in the Western Alps, where information on past events are exhaustive and characterized by a long historical series. More than 769 documented torrential events occurred from 1728 to 2015 within 78 catchments. Datasets concerning climate, geology and morphology, land use and the presence of historical landslide activity have been elaborated as input for multivariate statistical analysis to characterize the behavior of the catchments. The results pinpoint the factors that mainly drive the type of torrential dominant process occurring in a given catchment, its occurrence probability, and its frequency. This study has demonstrated that catchments characterized by a significant percentage of outcropping rocks show a greater occurrence of torrential processes, especially hyperconcentrated flows and debris flows; on the contrary highly vegetated catchments are typically subject to water flows. This result can be a useful tool for the evaluation of hazards related to this specific phenomenon, making it possible to predict the most likely torrential processes that can be generated in a specific catchment, given the characteristics of outcropping rock and vegetation cover.

Keywords: debris flow, hyperconcentrated flow, alpine catchment, torrential process, hazard assessment

\section{INTRODUCTION}

Torrential processes affecting alpine catchments are one of the most common phenomena causing economic losses and casualties in the alpine region (Govi and Sorzana, 1980; Tropeano and Turconi, 1999; Tropeano et al., 1999, 2006; Arattano et al., 2010; Tiranti and Rabuffetti, 2010).

Intense rainfall is the most common triggering factor of torrential processes in the alpine environment, especially below $2000 \mathrm{~m}$ asl because, at higher altitudes, the occurrence of torrential processes is driven by factors linked to the periglacial environment (i.e., snowmelt, glacial outburst flood and permafrost degradation; Govi et al., 1985; Cojean, 1994; Fuchu et al., 1999; Palacios et al., 1999; Wieczorek and Glade, 2005; Chiarle et al., 2007; Cannon et al., 2008; Tiranti et al., 2008, 2014; Stoffel et al., 2011, 2014; Brunetti et al., 2015; Marra et al., in press). Previous studies conducted in the Alps have shown that the occurrence of torrential processes with mass transport is closely related to some predisposing factors, such as the lithological setting of the 
catchments and the fracturation degree of the outcropping rocks (Lin et al., 2000; Moscariello et al., 2002; Tiranti et al., 2008, 2014; Tiranti and Deangeli, 2015), the morphology of the catchments (Lin et al., 2002; Ohlmacher and Davis, 2003; Ranjan et al., 2004; Wilford et al., 2004; Chang and Chao, 2006; Chang, 2007; Chang and Chien, 2007; Lu et al., 2007; Tunusluoglu et al., 2008) and the land cover (Lin et al., 2002; Wilford et al., 2004; Catani et al., 2005; Lee and Pradhan, 2007; Lu et al., 2007) and the presence of landslides activity within the catchments (Campbell, 1974; Johnson and Rodine, 1984; Sassa, 1985; Ellen and Flaming, 1987; Iverson et al., 1997; Blair, 1999; Gregoretti, 2000; Lin et al., 2002; Reid et al., 2003; Maleta et al., 2005).

While the morphometric and lithological influence on the occurrence of torrential processes are widely investigated in literature, the role of the vegetation cover has been mainly treated in connection with the triggering of landslides (Campbell, 1974; Styczen and Morgan, 1995; Schmidt et al., 2001; van Beek and van Asch, 2004; Sekhar et al., 2006; Santi et al., 2008). The role that it plays in preventing torrential phenomena is not present in such detail in literature; in fact, the majority of articles deals with the effects of wood in the runout of torrential processes (Tinker and Knight, 2000; Lancaster et al., 2003; Zelt and Wohl, 2004) and hydrological response (Doerra et al., 2006; Shakesby and Doerr, 2006; Kean et al., 2013).

This study intends to correlate in a statistical way all the mentioned factors, including land use, to understand how they interact with each other and which of these most influences the triggering of torrential phenomena characterized by mass transport.

The study was conducted in Susa Valley, a particular valley of the Western Italian Alps where, in a relatively small area, a high variability of geological, geomorphological, and vegetation distribution is present, as is very abundant data on historical torrential process events. It is very important to understand the torrential process behavior (Tropeano and Turconi, 2004; Turconi et al., 2014) as these conditions can provide statistical relevance to the analysis and representativeness of the whole Alpine environment.

\section{THE STUDY AREA}

The Susa Valley extends about $1337 \mathrm{~km}^{2}$ in the Italian Western Alps from the Po valley to the borderline with France (Figure 1). The Dora Riparia river is the main steam of the drainage valley system. According to Polino et al. (2002) and Cadoppi et al. (2002), from a geological point of view, the valley lies in the paleogeographic domains of Brianzonese and Piemontese, within the Pennidic domain, respectively representing the following paleoenvironment:

(1) Continental Margin domain, which includes continental crust units and Mesozoic carbonate or incertae sedis covers. This domain includes the Ambin and the Dora-Maira, which feature inner massive crystalline metamorphic complexes. The deeper tectonostratigraphic unit is the Ambin Complex, an outcropping on the left side of the Susa Valley that consists of Pre-Triassic crystalline basement and Mesozoic

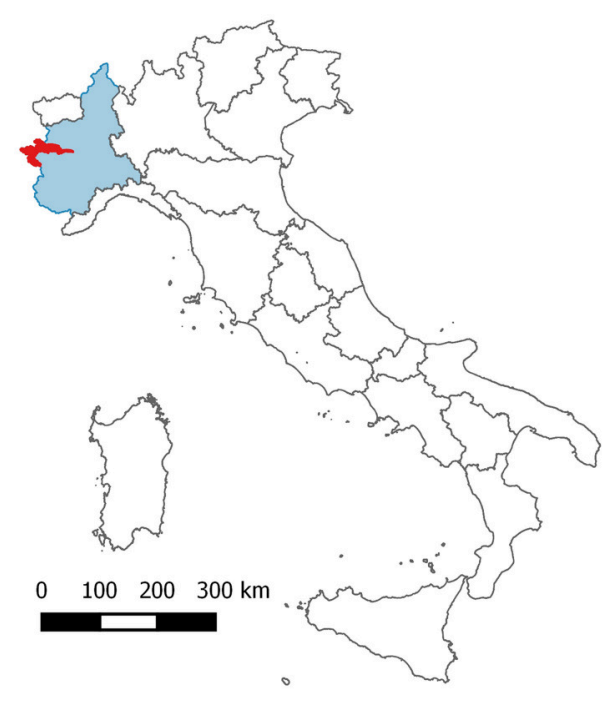

FIGURE 1 | The Susa Valley in red, the Piemonte region in light blue.

metasediments. The massif is formed by two different complexes, the Clarea Group (at the bottom) and the Ambin Group (Borghi and Gattiglio, 1997). The Dora-Maira Massif consists of a Paleozoic basement and carbonate Mesozoic metasediment. The other tectonostratigraphic units belonging to this domain are the Vallonetto Unit, the Gad Unit, the Unit of Valfredda ChabertonGrand Hoche-Grand Argentier and the Unit of Tre Re Magi.

(2) Oceanic and Fossa domains consist of ophiolites and Ligurian-type sedimentary sequences. In the lower Susa Valley the main ophiolitic unit is the Cerogne-Ciantiplagna, while the Fossa units are represented by the Calc-schists with Green Stones, Calc-schists of Puys-Venaus, the ChiomonteVenaus and Rocciamelone complexes.

During the Quaternary the Susa valley was subject to the action of the glaciers, which resulted in its typical " $U$ "-shaped cross section, in the formation of moraines and glacial deposits on both valley slopes. During the post-glacial period, numerous deepseated landslides formed as a result of the stress released by the glaciers melting. Deep-seated gravitational slope deformations (DSGSD) are quite relevant for their contribution to the morphogenesis of the Susa Valley, due to a slow and progressive deformation of rock masses.

The Susa Valley is characterized by xeric climate with a low rainfall regime: the average annual rainfall is about $600-900 \mathrm{~mm}$. Due to the rise of moist air from the plains, the annual rainfall is relatively higher in the lower part of the valley, while the number of rainy days decreases proceeding to the valley head (Biancotti et al., 1998; Fratianni and Motta, 2002).

Due to its peculiar position, the Susa valley is the crossroads of different vegetation species characteristic of the surrounding Maritime, Cottian and Central Alps. A considerable wealth of flora (about 3000 species) and diversity of plant formations are present in the area. The treeline can be identified at $2400 \mathrm{~m}$ 
asl, but in certain cases it reaches $2600 \mathrm{~m}$ asl. While on the northern faces there are abundant forests, on the opposite faces there is a greater variety of flora due to climate variability (Perosino and Zazzara, 2006). On the southern side, beyond deciduous forest residues, including species such as oak (Quercus pubescens) and Holm oak (Quercus ilex), meadows, pastures and crops are present up to $1000 \mathrm{~m}$ altitude (Montacchini et al., 1982).

\section{Lithologic Characterization}

In order to characterize the catchments and the torrential phenomena that affect them, the alpine basins are classified by the Clay Weathering Index (CWI) according to Tiranti et al. (2014). This index identifies the predisposition of rock masses to produce clay or clay-like minerals in loose material, as a result of alteration/disintegration processes. This classification considers the influence of the fine-grained sediments on the torrential processes. In fact, the clay amount drives the depositional style and pattern of debris flows, their frequency and seasonality, the flow rheology and the architecture of the alluvial fans (Tiranti and Deangeli, 2015).

The CWI identifies three catchment types:

- Excellent Clay Maker (ECM): catchments mainly formed by sedimentary rocks rich in clay or fine-grained and foliated metamorphic rocks, or volcanic rocks that produce significant quantities of clay (Figure 2A). In case of mass transport, the flow rheology is viscoplastic; the main occurrence happens during summer with triggering rainfall of intensities greater than $20 \mathrm{~mm} / \mathrm{h}$, i.e., characterized by a return-period of five years in the Susa Valley;

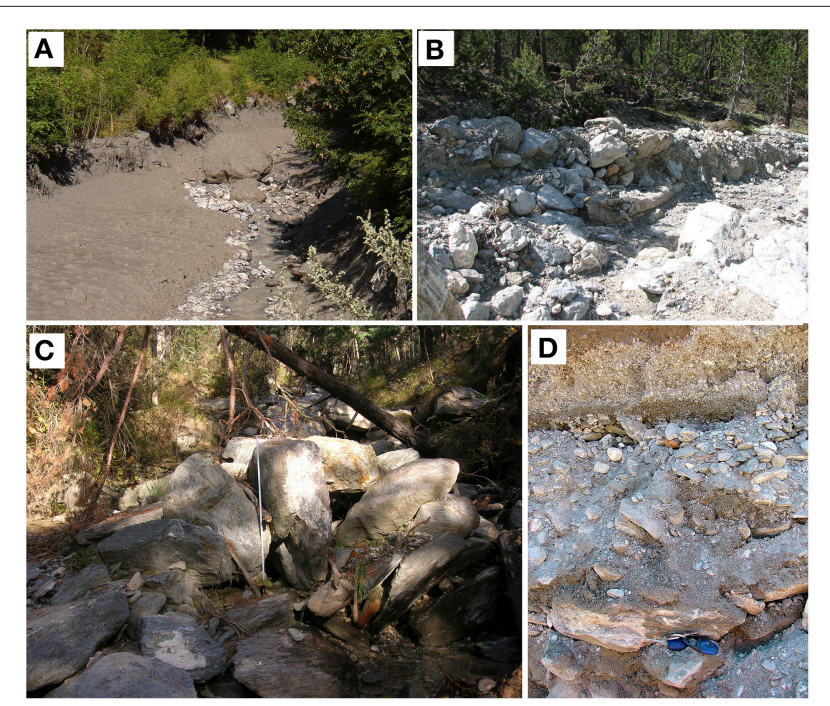

FIGURE 2 | (A) Example of very muddy hyperconcentrated flow deposit with rare boulders from Rio Fenils ECM catchment, Cesana municipality, Susa Valley; (B) Example of debris flow deposit with abundant boulders in a clayey silt matrix from Comba Crosa GCM catchment, Cesana municipality, Susa Valley. (C) Example of partially open-work hyperconcentrated flow deposit with very abundant boulders. (D) Detail of matrix formed by sand, gravel and silt. From Rio Secco BCM catchment, Salbertrand municipality, Susa Valley.
- Good Clay Maker (GCM): catchments mainly formed by massive carbonate rocks that produce moderate quantities of clay or clayey silt (Figure 2B). In case of mass transport, the flow rheology is viscoplastic; the main occurrence happens during late spring with triggering rainfall intensity greater than $30 \mathrm{~mm} / \mathrm{h}$, i.e., characterized by a return-period of 20 years in the Susa Valley;

- Bad Clay Maker (BCM): catchments mainly formed by coarsegrained and massive metamorphic or magmatic rocks that produce negligible quantities of clay (Figures 2C,D). In case of mass transport the flow rheology is frictional-collisional, the main occurrence happens during fall with triggering rainfall intensity greater than $50 \mathrm{~mm} / \mathrm{h}$, i.e., characterized by a returnperiod of 100 years in the Susa Valley.

To determinate the rock mass quality, the Geological Strength Index (Hoek and Brown, 1997; Hoek and Marinos, 2001; Hoek et al., 2002; Marinos et al., 2004a,b, 2005; Tiranti et al., 2008) is applied as a rule-of-thumb to each lithology forming the tectonostratigraphic units.

Due to complex lithology of the Susa Valley catchments, the lithotypes were grouped in three major lithogroups: massive limestones and dolostones (including marbles), massive coarsegrained crystalline rocks (metabasites, ophiolites, gneisses, mica schists, and quartzites) and foliated fine-grained metamorphic

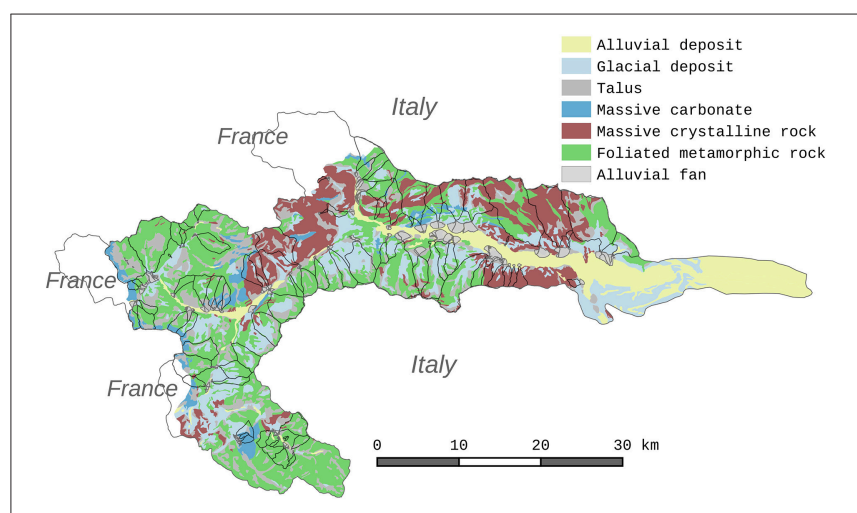

FIGURE 3 | Lithology map of catchments having torrential events data.

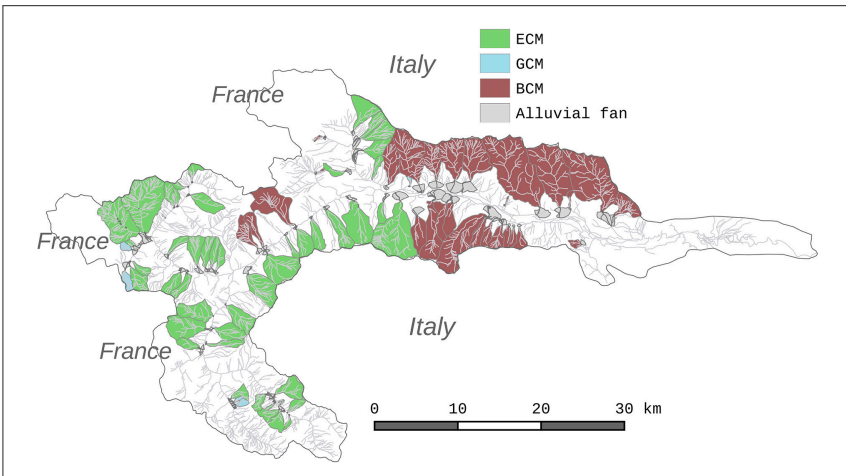

FIGURE 4 | Catchments CWI classification based on dominant lithology. 
TABLE 1 | Correspondence between CWI classes and the average GSI (adapted from Tiranti et al., 2008).

\begin{tabular}{lc}
\hline CWI class & Average GSI \\
\hline ECM & 45 \\
GCM & 60 \\
BCM & 75
\end{tabular}

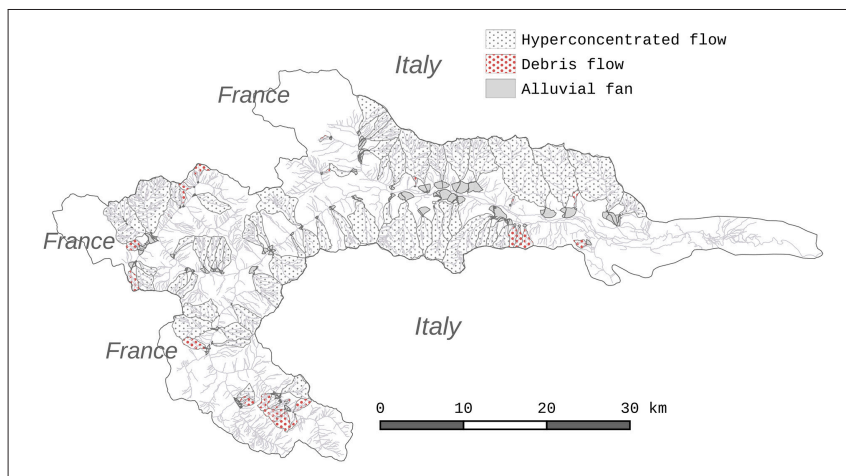

FIGURE 5 | More likely torrential process that reaches the alluvial fan.

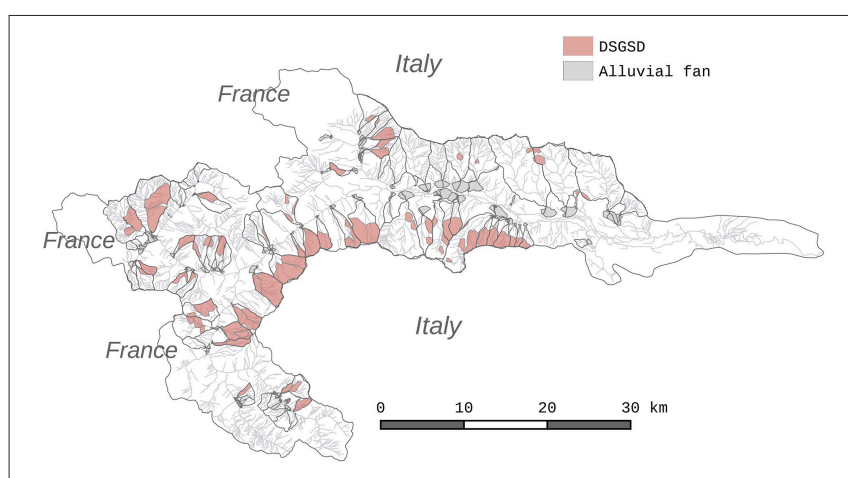

FIGURE 6 | DSGSD distribution along the Susa Valley.

rocks (calc-schists, shales, carbonate schists, and phyllades: Figure 3).

Figure 4 shows that the most abundant lithogroup is represented by the foliate grain-fined metamorphic rocks covering about $52.44 \%$ of the total lithotypes in the areas considered; the massive coarse-grained crystalline rocks are present for $38.57 \%$, while the massive carbonates account for only $8.99 \%$. The surface deposits represent about $31 \%$ of the total area.

Based on the dominant lithology, about 48 catchments are classified as ECM, 26 as BCM and only 4 were classified as GCM (Figure 6).

The GSI is applied for the characterization of rock masses, because the structural characteristics of the entire Susa Valley are evenly distributed within the same lithology, and therefore the structural variety is limited. For each CWI main group, the GSI mean values are calculated. Table 1 shows the correspondence between CWI classes and the average GSI.
TABLE 2 | Landslide types and abundance (A.A.V.V., 2015) ${ }^{1}$.

\begin{tabular}{lcc}
\hline Landslide type & $\begin{array}{c}\text { Covered } \\
\text { area } \mathbf{( \mathbf { k m } ^ { 2 } )}\end{array}$ & $\begin{array}{c}\text { Relative } \\
\text { abundance (\%) }\end{array}$ \\
\hline Rockfalls and topples & 59.94 & 41.33 \\
Shallow landslides & 6.20 & 4.28 \\
Slow earth flows & 10.03 & 6.91 \\
Earth flows & 0.53 & 0.37 \\
Complex landslides & 55.03 & 37.95 \\
Rotational and translational slides & 13.30 & 9.19
\end{tabular}

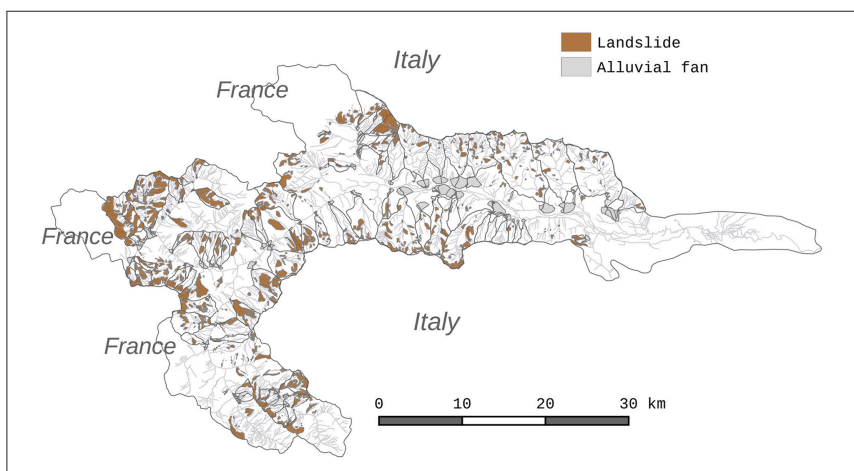

FIGURE 7 | Landslides distribution along the Susa Valley.

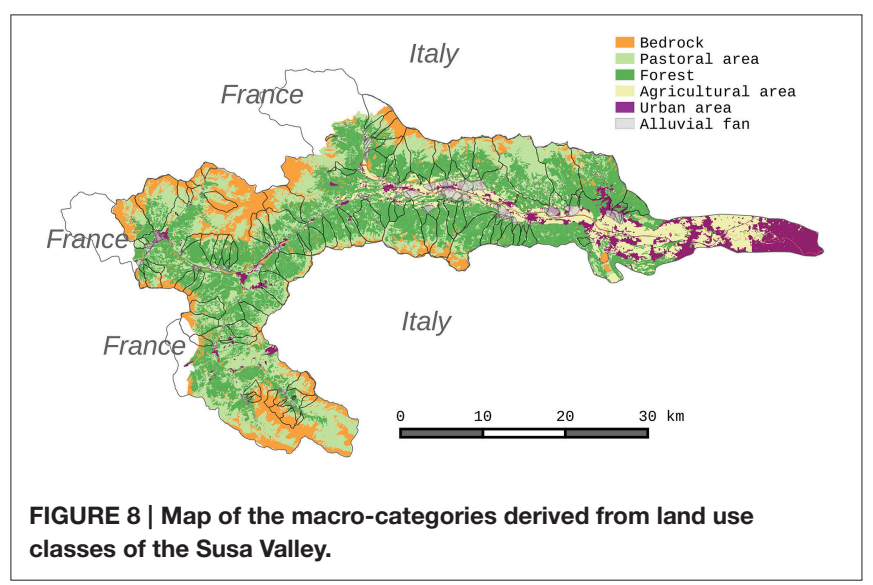

\section{Morphometric Characterization}

The morphometric characterization of the catchments is based on Wilford et al. (2004), which determines the most likely torrential process reaching the alluvial fan area considering a complete set of morphometric parameters. This characterization is derived from LiDAR based 5-m resolution digital terrain model (DTM) covering the Susa Valley. The torrential processes taken into consideration are water flows (WF) with a low sediment concentration (0-20\%), transported by bedloading in flow mixture characterized by a Newtonian behavior; also

${ }^{1}$ A.A.V.V. (2015) SIFraP - Landslides Information System of Piemonte, Arpa Piemonte. Available online at: http://webgis.arpa.piemonte.it/geoportalserver_ $\mathrm{arpa} / \mathrm{catalog} / \mathrm{search} / \mathrm{resource} /$ details.page?uuid=ARLPA_TO\%3A07.04.02-D_ 2011-03-24-11\%3A43. 
called debris floods, hyperconcentrated flows (HF) are torrential mass movements with moderate sediment concentration (20-50\%) in flow mixture characterized by a Newtonian or nonNewtonian behavior depending on the sediments concentration; debris flows (DF) are torrential mass movement with high sediment concentration (50-85\%) in flow mixture characterized

\section{TABLE 3 | Land use macro-categories of the Susa Valley.}

\begin{tabular}{lll}
\hline Land use group & Area $\mathbf{( k m}^{\mathbf{2}}$ ) & Distribution (\%) \\
\hline Grassland & 238.12 & 31.91 \\
Forest & 358.96 & 48.09 \\
Agricultural area & 3.63 & 0.49 \\
Urban Area & 5.51 & 0.74 \\
Bedrock & 140.03 & 18.77
\end{tabular}

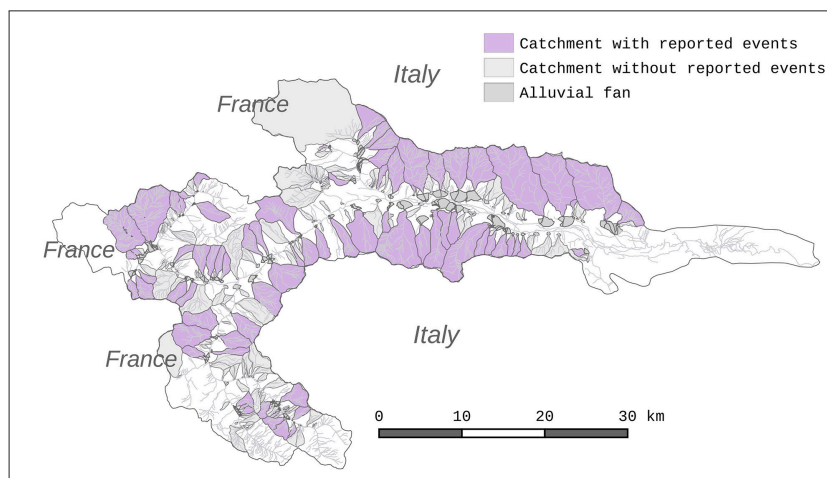

FIGURE 9 | Catchments having torrential events historical information. by non-Newtonian viscoplastic or collisional-frictional behavior depending on the fine sediment amount (Pierson and Costa, 1987; Costa, 1988; Lavigne and Suwa, 2004).

To establish the propensity of a catchment to generate a specific torrential phenomenon, the morphometric characterization is mainly based on the Melton ratio (Melton, 1957) and the length of watershed. Basically, a catchment characterized by a Melton ratio $<0.3$ and a watershed length $>8$ $\mathrm{km}$ is more subject to water flows, while the debris flows are characteristic of catchments with a Melton ratio $>0.6$ and watershed length $<3 \mathrm{~km}$. Hyperconcentrated flows affect catchments with a Melton ratio $>0.3$ and watershed length values between 3 and $8 \mathrm{~km}$.

Applying Wilford et al. (2004), most of the Susa Valley catchments are characterized by hyperconcentrated flows as main processes (average Melton ratio of 0.74 and watershed length $<8 \mathrm{~km}$ ). Only 27 catchments out of 78 are more likely to trigger debris flows (average Melton ratio of 3.50 and watershed

TABLE 4 | Torrential events occurrence per catchment class in the Susa Valley.

\begin{tabular}{lllll}
\hline & $\begin{array}{l}\text { Number } \\
\text { of DF }\end{array}$ & $\begin{array}{l}\text { Number } \\
\text { of HF }\end{array}$ & $\begin{array}{l}\text { Number } \\
\text { of WF }\end{array}$ & $\begin{array}{l}\text { Number of total } \\
\text { torrential events }\end{array}$ \\
\hline $\mathrm{ECM}$ & 84 & 222 & 97 & 415 \\
$\mathrm{ROI}$ & 0.37 & 0.97 & 0.43 & 1.82 \\
$\mathrm{BCM}$ & 3 & 75 & 227 & 305 \\
$\mathrm{ROI}$ & 0.01 & 0.33 & 1.00 & 1.34 \\
$\mathrm{GCM}$ & 43 & 6 & 0 & 49 \\
$\mathrm{ROI}$ & 9.39 & 1.31 & 0.00 & 10.70
\end{tabular}

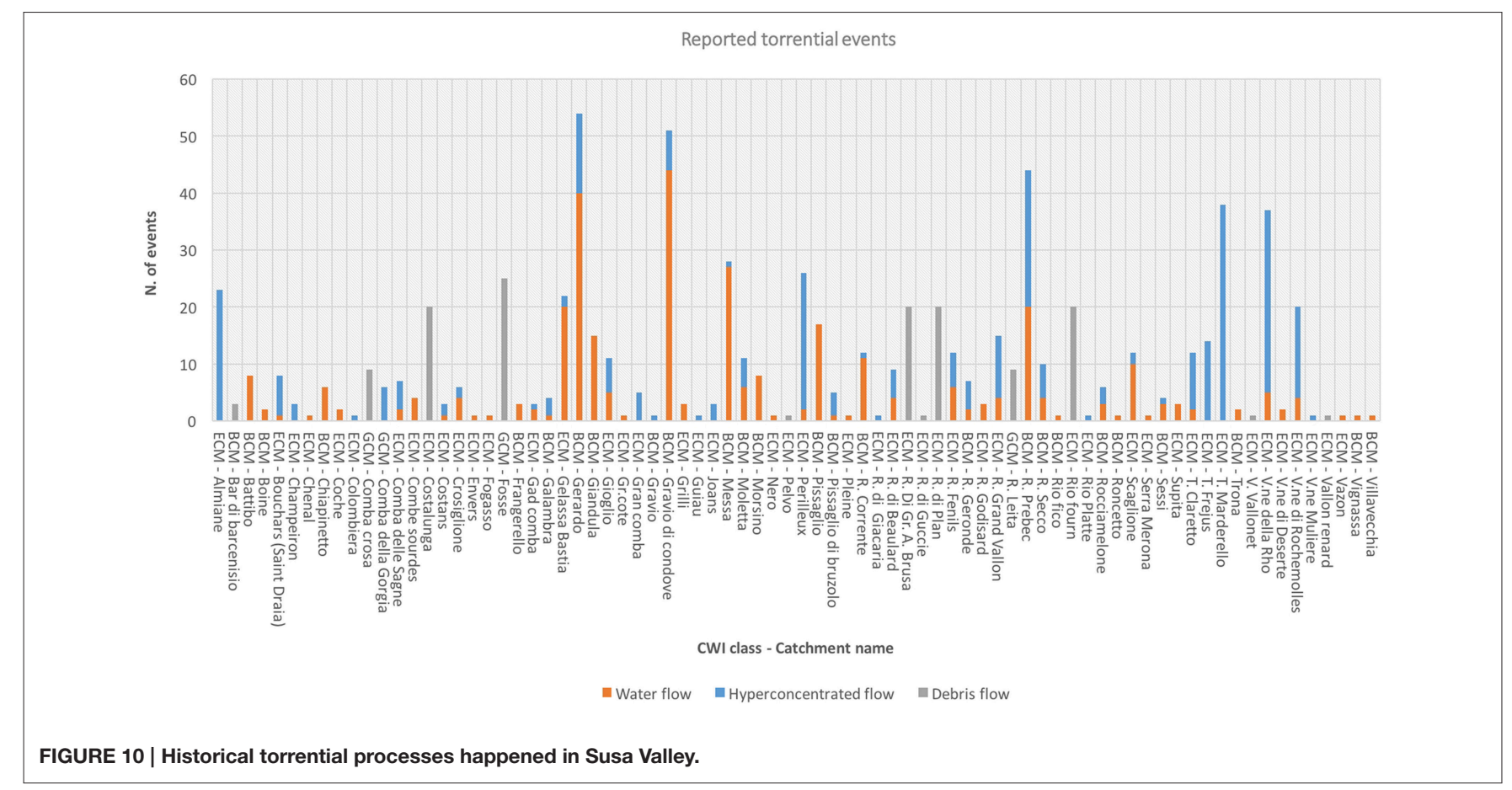


A

ECM catchments

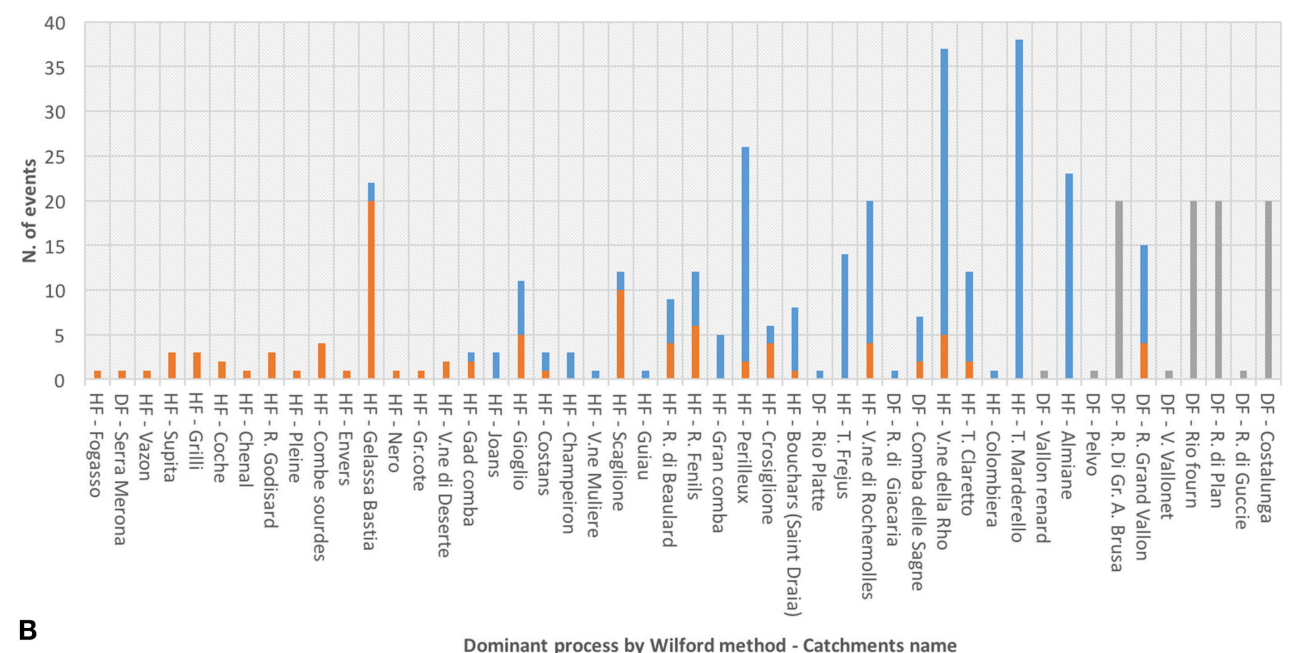

GCM catchments

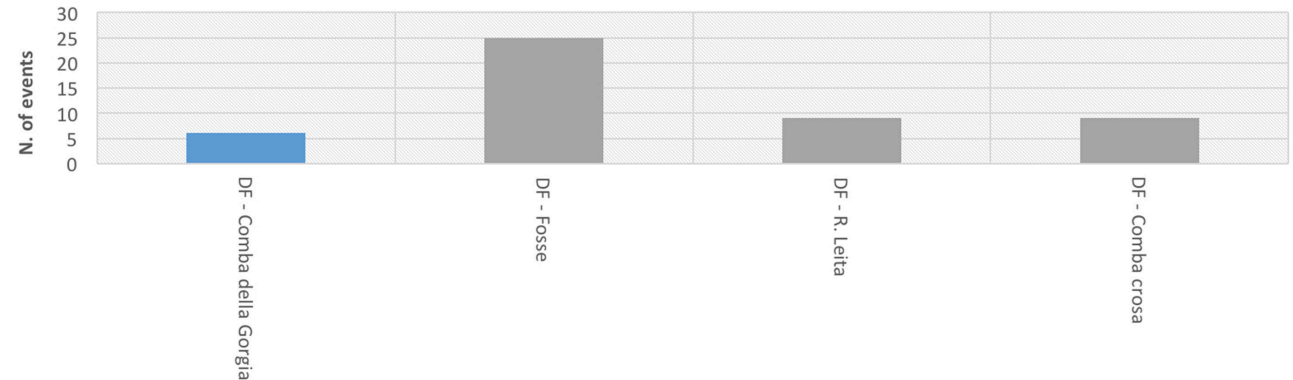

C

Dominant process by Wilford method - Catchment name

BCM catchments

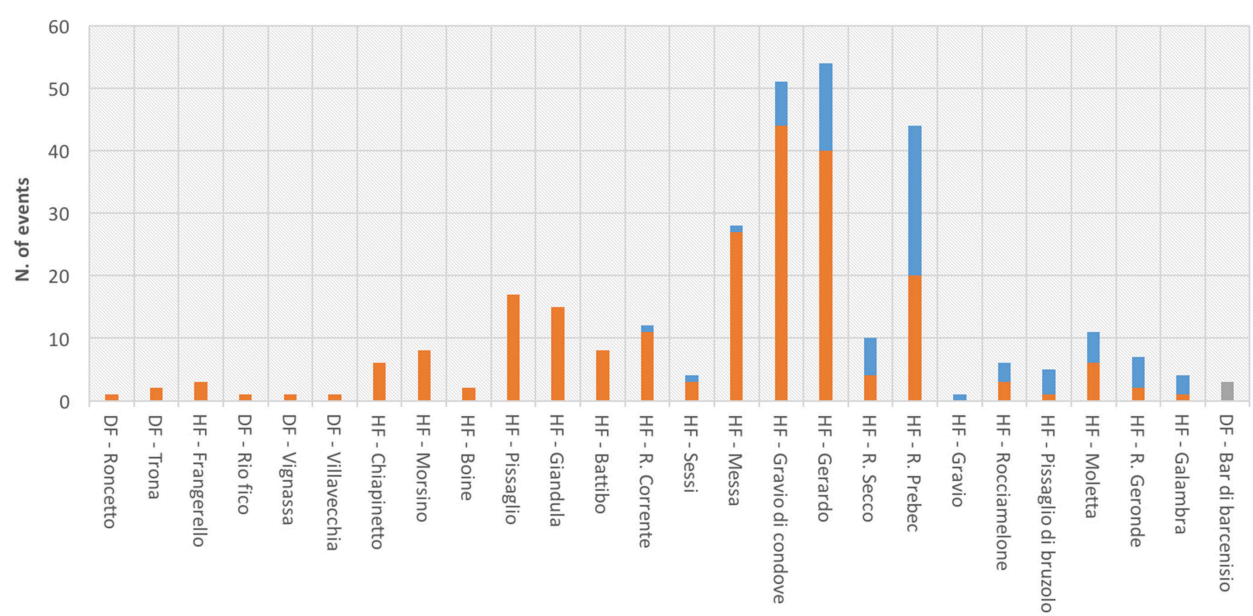

Dominant process by Wilford method - Catchments name

घater flow $\quad$ Hyperconcentrated flow Debris flow

FIGURE 11 | The torrential events distinguished by processes type occurred in the three CWI catchment classes: (A) ECM catchments; (B) GCM catchments; (C) BCM catchments. 
A

ECM catchments

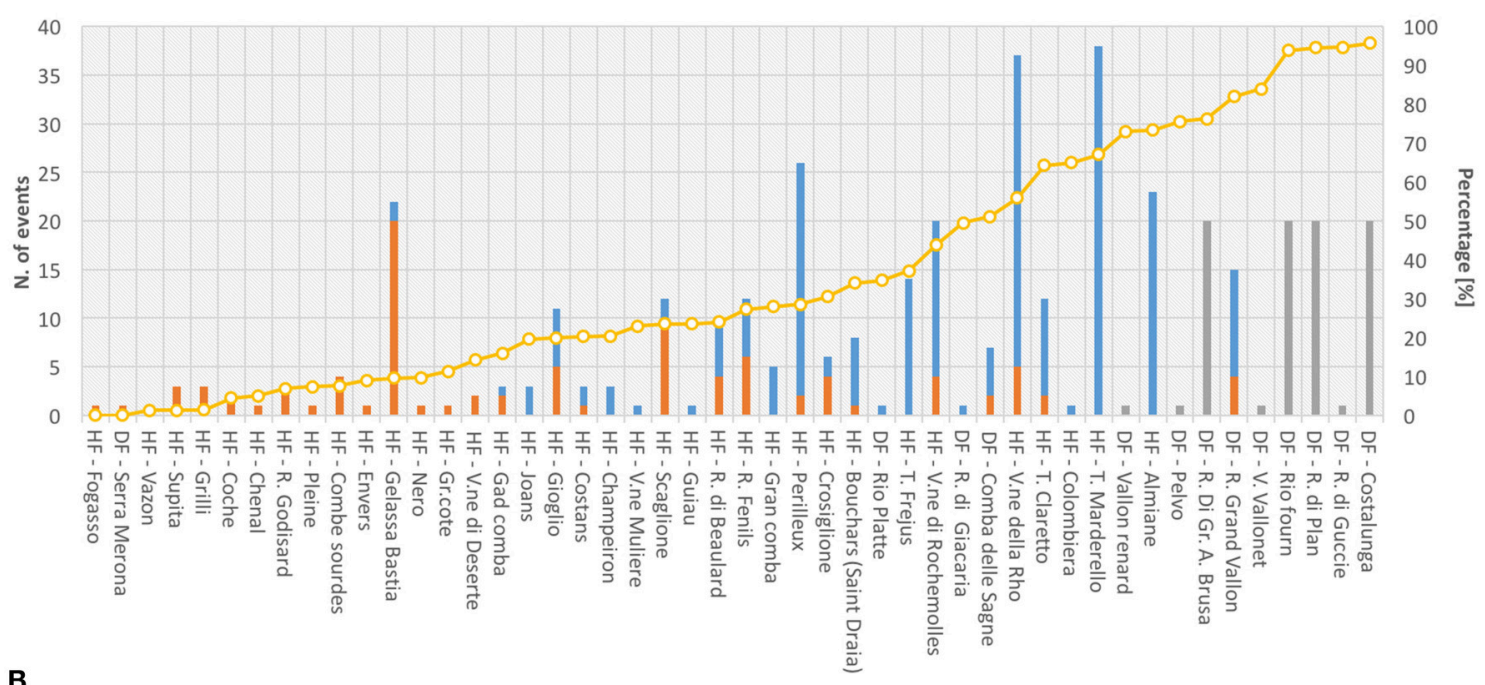

Dominant process by Wilford method - Catchments name

ECM catchments

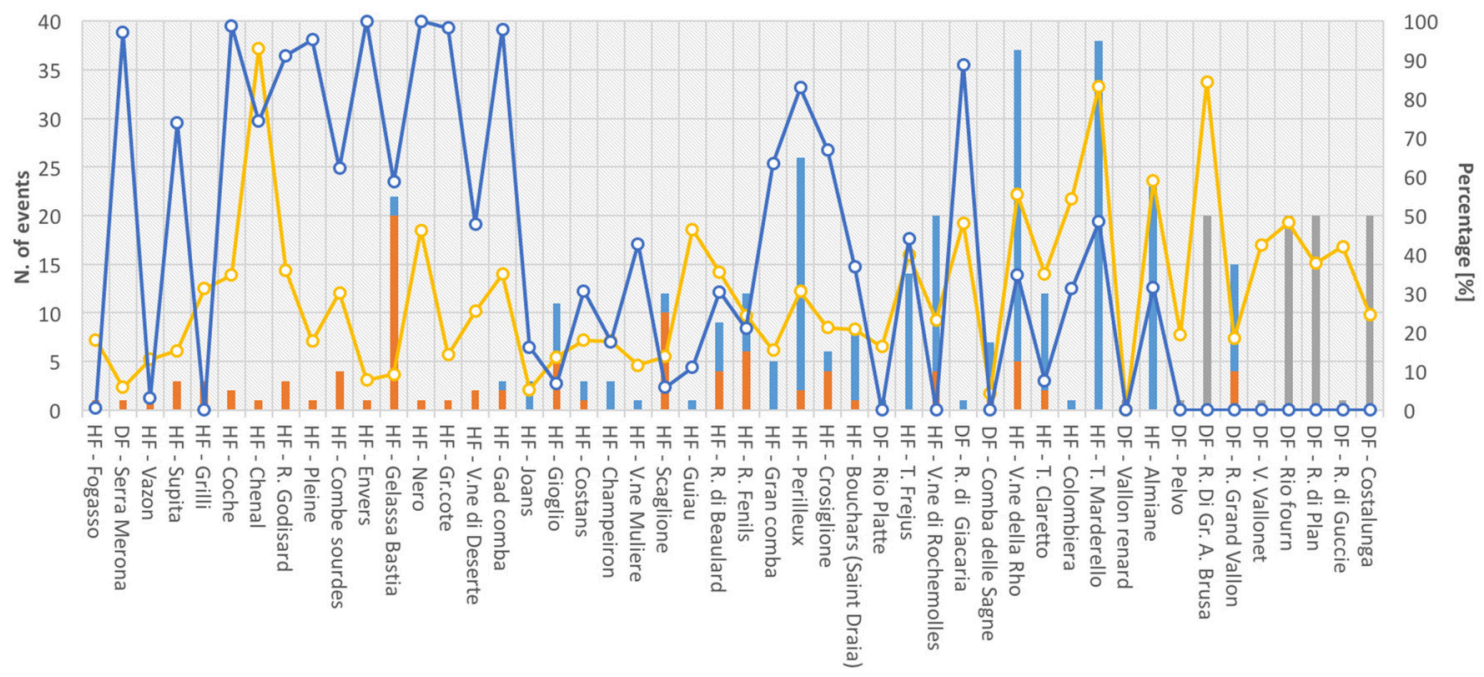

Dominant process by Wilford method - Catchments name

Water flow Hyperconcentrated flow Debris flow -0 -Landslides [\%]

FIGURE 12 | (A) Correlation of torrential events and outcropping bedrock percentage; (B) landslides and DSGSD distribution (\%) in ECM catchments.

length $<3 \mathrm{~km}$; Figure 5). None of the selected catchments fall in the "water flow" class.

\section{Landslides Distribution}

According to some authors (Campbell, 1974; Johnson and Rodine, 1984; Sassa, 1985; Ellen and Flaming, 1987; Iverson et al., 1997; Blair, 1999; Gregoretti, 2000; Lin et al., 2002; Reid et al., 2003; Maleta et al., 2005), landslide occurrence within catchments seems to contribute to the triggering of torrential processes in two ways:
- landslides can directly trigger a mass transport along the main channel;

- their deposits constitute an important source of sediment for channel-bed failure initiation.

Finally, the distribution of deep-seated gravitational slope deformations (DSGSD) is analyzed to investigate their possible influence on the occurrence of torrential processes. The DSGSD cover about $181.78 \mathrm{~km}^{2}$, corresponding to the $21.68 \%$ of the Susa Valley. The other types of landslides cover 
A

GCM catchments

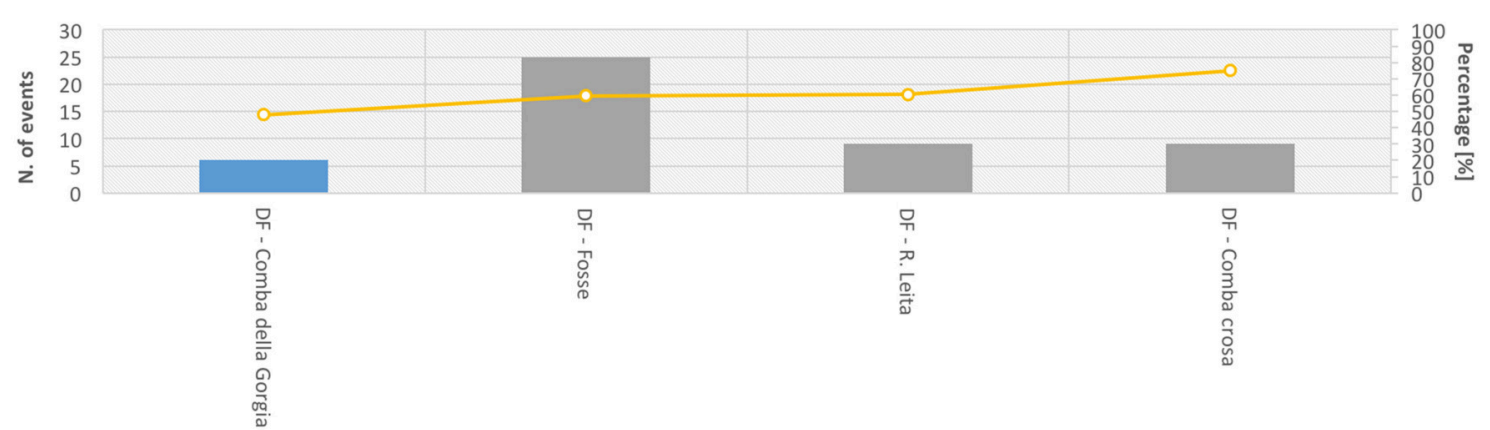

B

Dominant process by Wilford method - Catchment name

Water flow - Hyperconcentrated flow Debris flow -0 -Outcropping bedrock [\%]

GCM catchments

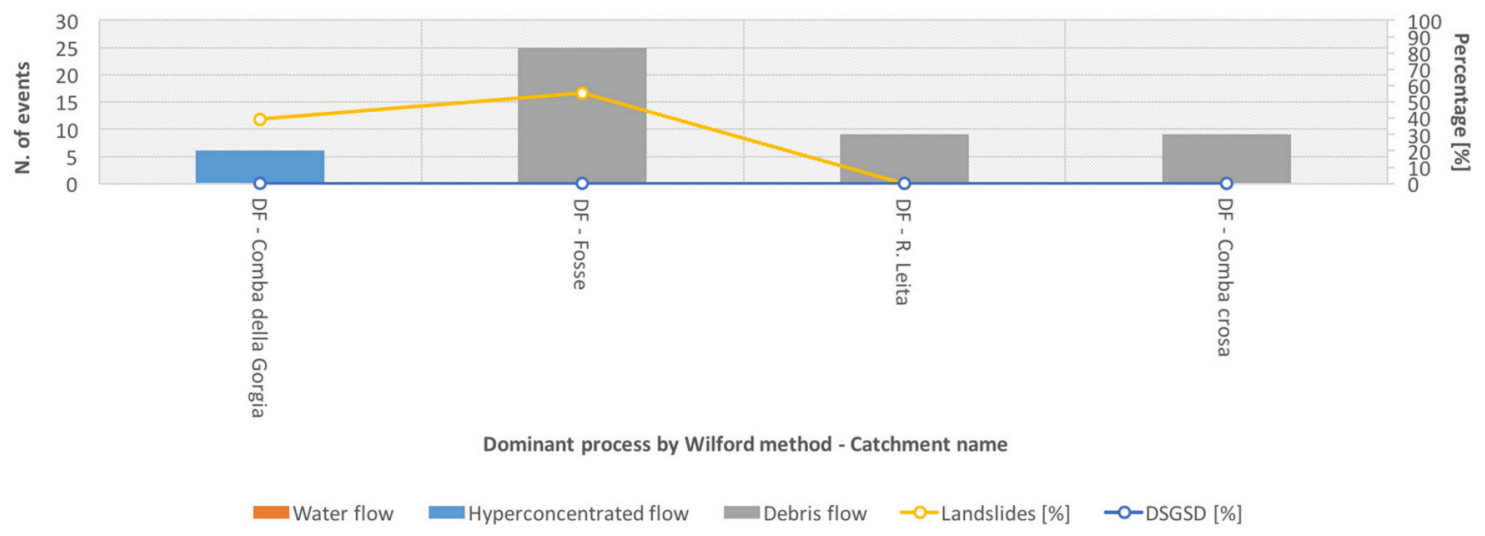

FIGURE 13 | (A) Correlation of torrential events and outcropping bedrock percentage; (B) landslides and DSGSD distribution (\%) in GCM catchments.

$145.03 \mathrm{~km}^{2}$, corresponding to the $17.30 \%$ of the total area (Figure 6).

The landslide types that have occurred in the Susa Valley and their relative amount are shown in Table 2.

Table 2 reports the landslide type fraction in the catchments. Figure 7 shows the spatial distribution of landslides in the Susa valley, except DSGSD.

\section{Land Cover Characterization}

Regarding the land use of the Susa Valley, the 35 different land use types shown in the land use map at 1:10,000 scale (A.A. V.V., 2009) ${ }^{2}$ are remapped in four macro-categories (Figure 8) based on similar characteristics: all trees classes and bushes are classified as "Forest"; grassland and pastoral areas are classified as "Grassland"; crops, orchards and vineyards are classified as "Agricultural area"; outcropping bedrock including sub-outcrop, float materials and talus are classified as "Bedrock" (Table 3).

Nearly $600 \mathrm{~km}^{2}$, corresponding to $80 \%$ of the Susa Valley, are covered by vegetation. Agricultural and urban areas together

\footnotetext{
${ }^{2}$ A.A.V.V. (2009) Piani Forestali Territoriali (PFT), IPLA and Ragione Piemonte. Available online at: http://www.regione.piemonte.it/foreste/it/gestione/ pianificazione/pft.html.
}

occupy slightly more than $1 \%$ of the total area and they are concentrated in the lower part of the valley, out of selected catchments. Outcropping rocks cover about $19 \%$.

\section{ANALYSIS OF HISTORICAL TORRENTIAL PROCESSES}

Torrential processes that have occurred in the Susa Valley have been scrupulously documented: sources of information comes from municipalities and church archives, scientific publication or technical reports and collected in public databases (Geological Database of the Regional Agency for Environmental Protection of Piemonte-http://webgis. arpa.piemonte.it/bdge/index.php_integrated by data from CNR-IRPI-http://polaris.irpi.cnr.it/). Information includes date, sometimes daytime, location, flow type (water flow, hyperconcentrated flow and debris flow) and damages.

The analysis of historical documentation indicates that only 78 of 208 catchments of the Susa Valley reported events from 1728 to 2015 as result of databases interrogation (Figure 9). 
For the period between 1943 to 1945, during the 2nd War World, there is a lack of information. The number of reports shows a maximum during the twentieth century, while only six reports are considered valid before 1800. Information dating prior to 1940 is less reliable: in these cases the process type was derived by interpreting the available information and adapting them to the modern scientific nomenclature to classify torrential phenomena (Jakob and Hungr, 2005).

Seven hundred and sixty-eight torrential processes that occurred in 78 catchments were collected and characterized.
The overall results of this historical research are summarized in Figure 10.

The analysis reported 415 documented events in ECM catchments, 305 in BCM, and only 49 in the GCM. The number of events per CWI class must be normalized by the area of catchments within each class. The ECM catchments represent the class with the greatest abundance (48) of catchments, covering a total area of $227.91 \mathrm{Km}^{2}$, followed by the BCM class $(29$ catchments covering $226.92 \mathrm{Km}^{2}$ ), while the class GCM is represented by only 49 catchments, occupying an area of 4.58

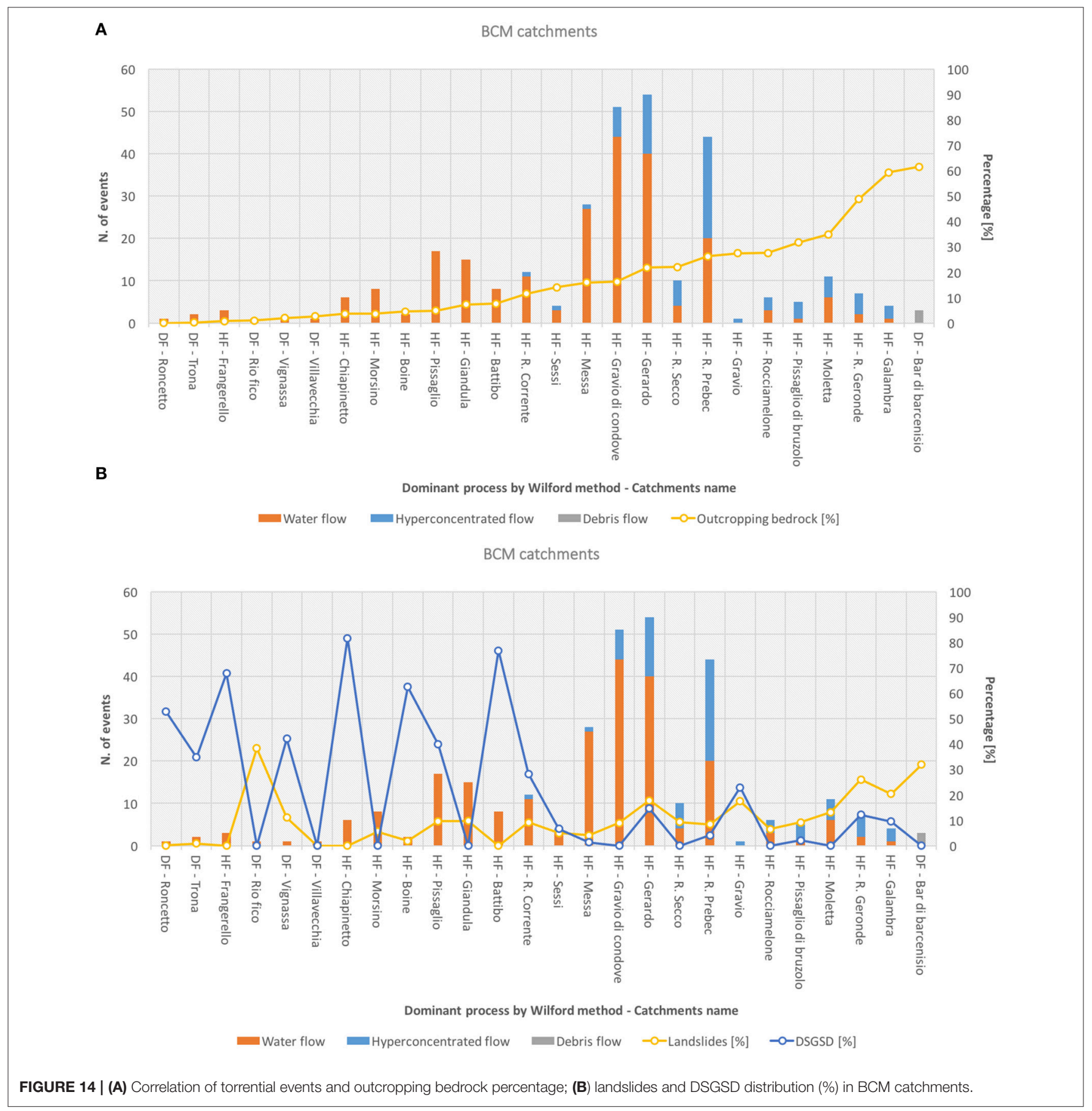




\section{Outcropping bedrock fraction vs process $\mathrm{ROI}$}
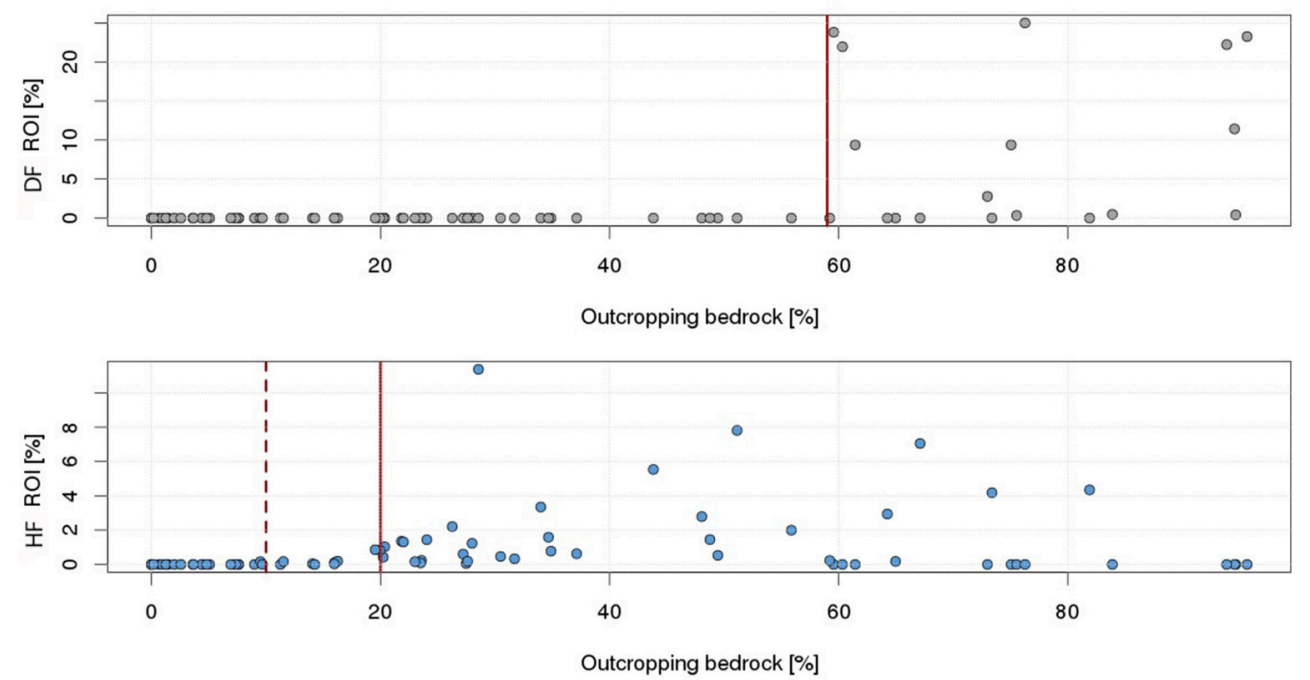

FIGURE 15 | Outcropping bedrock thresholds for torrential processes type.

$\mathrm{Km}^{2}$. The normalization of event occurrence per catchment class is expressed by the Relative Occurrence Index (ROI) given by the number of events divided by the total area covered by catchments referred to each CWI class (Table 4).

The ECM catchments are indeed characterized by 1.82 ROI, while the BCM is characterized by 1.34 . Although the total number of events for GCM is considerably less than the other two classes, the ROI value is 10.70 , indicating a high occurrence of torrential processes.

Table 4 shows also the ROI calculated by distinguishing the type of process that occurred: water flow (WF), hyperconcentrated flow (HF), and debris flow (DF). Analysing the ROI values in Table 4, it is clear that the ECM catchments generate a higher number of mass transports than the BCM catchments, which are most affected by water flows (Figure 11).

Although some ECM and BCM catchments are capable of generating mass transport, according to Wilford et al. (2004), only water flows are reported in them. To interpret this unexpected result and to understand the reasons for different behaviors, land use, landslide and DSGSD distribution must be taken into account. The following Figures correlate these parameters with the catchment activity (Figures 12A,B, 13A,B, 14A,B).

Multivariate statistical analysis (Johnson and Wichern, 1982) applied to Susa catchments shows that debris flows and hyperconcentrated flows are respectively strongly / moderately correlated with outcropping bedrock (Pearson correlation coefficient $\rho=0.533$ with $p<10-5, \rho=0.233$ with $p=$ $0.03)$. Water flows are negatively correlated with bedrock ( $\rho=$ -0.364 and $p=0.002$ ). The analysis shows also that landslides and DSGSD are statistically correlated respectively positively and negatively with outcropping bedrocks. As shown in Figure 15, when the outcropping bedrock is greater than $10 \%$ water flow processes could happen, HF becoming more likely for values greater than $20 \%$. This value increases to $59 \%$ for debris flows where both processes become highly probable.

The distribution of flow processes in the studied catchments varies according to the classification. Water flows are more likely to occur in BCM than in ECM while the opposite happens for debris flow. Hyperconcentrated flows are equally distributed in both types of basins. The GCM basins are not considered due to the limited dimension of the sample.

\section{CONCLUSIONS}

The occurrence of torrential processes depends on many factors, classifiable as triggering, predisposing and mitigating. As previously underlined, the main triggering factor of the torrential processes is the heavy rainfall preceding the initiation.

Starting with the analysis of historical information on past torrential events, this paper has investigated the factors that drive torrential phenomena types and occurrence in the Western Alps. The conditions mainly responsible for these phenomena have been identified and distinguished in predisposing and triggering factors. More than 769 documented torrential processes, which occurred from 1728 to 2015 within 78 catchments of the Susa Valley, were collected and analyzed. The datasets related to climate, geology and morphology, land use and the presence of historical landslides activity were elaborated as input of multivariate statistical analysis to characterize catchment behavior. The catchments studied were classified by the Clay Weathering Index, the Geological Strength index and the Wilford et al. (2004) method to establish the role of lithology and morphometric setting as predisposing factors for triggering the torrential processes. In some catchments potentially subject to mass transport, according to Wilford et al. (2004), only water flow processes were recorded. To understand the reason 
for this unexpected behavior, land use, landslides and DSGSD distributions were taken into account.

Among the predisposing factors, the catchment lithology characteristics (CWI) and morphometric settings (Wilford et al., 2004) play a key role. However, regardless of CWI class taken into consideration, it is clear that the main predisposing factor of the torrential process is the bedrock outcropping percentage (Figures 12, 13, 14). A higher percentage of outcropping bedrock enhances the debris production, which is the main source of mobilizable material. Although landslides can still be an important source of sediment in case of activation, they do not influence the torrential process characteristics (Figures 12B, 13B, 14B). Even DSGSD (Figures 12B, 13B, 14B) do not affect the behavior of torrential processes. This result can be explained considering that the DSGSD mainly affects slopes formed by schists (classified as ECM), which are already characterized by very poor geomechanical properties (see corresponding GSI class in Table 1), producing large amount of debris even in the absence of DSGSD. Therefore, the catchment sediment budget mainly depends on a high percentage of outcropping bedrock.

Consequently, vegetation appears to be the main mitigating factor of torrential mass movements. Vegetation controls the infiltration, increases the water suction surface, and reduces the runoff by the root system. The role of vegetation is particularly evident in highly vegetated catchments that are rarely subject to torrential processes and, in particular, to channelized mass movements (HF and DF).

\section{REFERENCES}

Arattano, M., Conte, R., Franzi, L., Giordan, D., Lazzari, A., and Luino, F. (2010). Risk management on an alluvial fan: a case study of the 2008 debris-flow event at Villar Pellice (Piedmont, N-W Italy). Nat. Hazards Earth Syst. Sci. 10, 999-1008. doi: 10.5194/nhess-10-999-2010

Biancotti, A., Bellardone, G., Bovo, S., Cagnazzi, B., Giacomelli, L., Marchisio, C. (1998). Regional Distribution of Rainfalls and Temperatures. Series Climatological Studies in Piedmont, Vol. 1. Torino: Regione Piemonte and Univ. degli Studi di Torino.

Blair, T. C. (1999). Alluvial fan and catchment initiation by rock avalanching, Owens Valley, California. Geomorphology 28, 201-221. doi: 10.1016/S0169555X(98)00111-1

Borghi, A., and Gattiglio, M. (1997). Osservazioni geologico-petrografiche nel settore occidentale del Massiccio d'Ambin. Atti Tic. Sc. Terra 5, 64-84.

Brunetti, M. T., Luino, F., Vennari, C., Peruccacci, S., Biddoccu, M., Valigi, D., et al. (2015). "Rainfall thresholds for possible occurrence of shallow landslides and debris flows in italy," in Dating Torrential Processes on Fans and Cones, Advances in Global Change Research, Vol. 47, eds M. Schneuwly-Bollschweiler, M. Stoffel, and F. Rudolf-Miklau (Springer), 327-342.

Cadoppi, P., Castelletto, M., Sacchi, R., Baggio, P., Carraro, F., and Giraud, V. (2002). Foglio 154 "Susa" Carta Geologica d'Italia. scala 1:50000. Servizio Geologico d'Italia.

Campbell, R. H. (1974). Debris flow originating from soil slip during rainstorms in southern California. Q.J. Eng. Geol. London 7, 339-349. doi: 10.1144/GSL.QJEG.1974.007.04.04

Campbell, R. H. (1975). "Soil slip, debris flows, and rainstorms in the Santa Monica Mountains and vicinity. Southern California," in U.S. Geological Survey Prof. Paper 851, 51.

Cannon, H. S., Gartner, J. E., Wilson, R. C., Bowers, J. C., and Laber, J. L. (2008). Storm rainfall conditions for floods and debris flows from recently burned
The plant populations most effective in torrential process mitigation are forests, because forest-land litter improves water infiltration and the underlying moist horizon stores water, thereby slowing the subsurface runoff (Figure 8). The aerial parts of plants intercept and partially hold the rainfall, reducing the drop impact energy and water sheet flow velocity up to four times compared to bare soil, resulting in a reduction of 16 times the erosion rate (Campbell, 1974, 1975; Cannon et al., 2001, 2008; Lancaster et al., 2003; Shakesby and Doerr, 2006).

The results show that the bedrock outcropping percentage is the dominant predisposing factor determining the torrential process type and frequencies. An outcropping bedrock area $>20 \%$ promotes the occurrence of hyperconcentrated flows and debris flows instead of water flows. Landslides and DSGSD distribution do not influence torrential process behavior.

This evidence makes it possible to distinguish the type of torrential processes occurring in alpine catchments with less uncertainty. Then, dedicated preventive actions can be implemented to mitigate the hazards related to torrential processes.

\section{AUTHOR CONTRIBUTIONS}

DT Responsible for the research work; expert in landslides and debris flows; Thesis Advisor of IA. IA Research collaborator within her MSc Thesis. RC Collaborator, expert in weather radar and rainfall analysis. FM Collaborator, expert in landslide and debris flow historical events.

areas in Southwestern Colorado and Southern California. Geomorphology, 96, 250-269. doi: 10.1016/j.geomorph.2007.03.019

Cannon, H. S., Kirkham, R. M., and Parise, M. (2001). Wildfire-related debrisflow initiation processes, Storm King Mountain, Colorado. Geomorphology 39, 171-188. doi: 10.1016/S0169-555X(00)00108-2

Catani, F., Casagli, N., Ermini, L., Righini, G., and Menduni, G. (2005). Landslide hazard and risk mapping at catchment scale in the Arno River basin. Landslides 2, 329-342. doi: 10.1007/s10346-005-0021-0

Chang, T. C. (2007). Risk degree of debris flow applying neural networks. Nat. Hazards 42, 209-224. doi: 10.1007/s11069-006-9069-y

Chang, T. C., and Chao, R. J. (2006). Application of back-propagation networks in debris flow prediction. Eng. Geol. 85, 270-280. doi: 10.1016/j.enggeo.2006.02.007

Chang, T. C., and Chien, Y. H. (2007). The application of genetic algorithm in debris flows prediction. Environ. Geol. 53, 339-347. doi: 10.1007/s00254-0070649-2

Chiarle, M., Iannotti, S., Mortara, G., and Deline, P. (2007). Recent debris flow occurrences associated with glaciers in the Alps. Glob. Planet. Change 56, 123-136. doi: 10.1016/j.gloplacha.2006.07.003

Cojean, R. (1994). "Contribution to the reduction of debris flow damage with the analysis of triggering factors, initiation, propagation and deposition phenomena in the Alpine region. Hydrological and hydrogeological risk," in Proceedings of the first review meeting, 341-359.

Costa, J. E. (1988). "Rheologic, geomorphic, and sedimentologic differentiation of water floods, hyperconcentrated flows, and debris flows," in Flood Geomorphology, eds V. R. Baker, R. C. Kochel, and R. C.Patton (New York, NY: John Wiley and Sons), 113-122.

Doerra, S. H., Shakesbya, R. A., Blakeb, W. H., Chaferc, C. J., Humphreysd, G. S., and Wallbrinke, P. J. (2006). Effects of differing wildfire severities on soil wettability and implications for hydrological response. J. Hydrol. 319, 295-311. doi: 10.1016/j.jhydrol.2005.06.038 
Ellen, S. D., and Flaming, R. W. (1987). Mobilization of debris flows from soil slips, San Francisco Bay region. Geol. Soc. Am. Rev. Eng. Geol. 7, 31-40. doi: 10.1130/REG7-p31

Fratianni, S., and Motta, L. (2002). Andamento climatico in alta Val Susa negli anni 1990-1999. Studi Climatol. Piemonte. 4. Regione Piemonte.

Fuchu, D., Lee, C. F., and Sijing, W. (1999). Analysis of rainstorm-induced slidedebris flows on natural terrain of Lantau Island, Hong Kong. Eng. Geol. 51, 279-290. doi: 10.1016/S0013-7952(98)00047-7

Govi, M., Mortara, G., and Sorzana, P. (1985). Eventi idrologici e frane. Geol. Appl. e Idrog. 20, 359-375.

Govi, M., and Sorzana, P. F. (1980). Landslide susceptibility as a function of critical rainfall amount in Piedmont basin (Northwestern Italy). Studia Geomorph. Carpatho-Balcanica, 14, 43-61, Krakow, 1980.

Gregoretti, C. (2000). Experimental evidence from the triggering of debris flow along a granular slope. J. Phys. Chem. Earth 25, 387-390. doi: 10.1016/S14641909(00)00031-9

Hoek, E., and Brown, E. T. (1997). Practical estimates of rock mass strength. Int. J. Rock Mech. Mining Sci. Geomechanics Abs 34, 1165-1186. doi: 10.1016/S13651609(97)80069-X

Hoek, E., Carranza-Torres, C., and Corkum, B. (2002). "Hoek-Brown failure criterion - 2002 Edition," in Proceedings of North American Rock Mechanics Society (Toronto, ON), 267-273.

Hoek, E., and Marinos, P. (2001). Estimating the geotechnical properties of heterogeneous rock masses such as flysch. Bull. Eng. Geol. Environ. 60, 85-92. doi: 10.1016/S1365-1609(97)80069-X

Iverson, R. M., Reid, M. E., and LaHusen, R. G. (1997). Debris flow mobilization from landslides. Annu. Rev. Earth Planet. Sci. 25, 85-138. doi: 10.1146/annurev.earth.25.1.85

Jakob, M., and Hungr, O. (2005). Debris-Flow Hazards and Related Phenomena. Heidelberg; Chichester: Springer-Verlag Praxis; Publishing Ltd.; Hardbound.

Johnson, A. M., and Rodine, J. R. (1984). “Debris flow," in Slope Instability, eds D. Brunsden, and D. B. Prior (Chichester: Wiley), 257-361.

Johnson, R. A., and Wichern, D. W. (1982). Applied Multivariate Statistical Analysis. Englewood Cliffs, NJ: Prentice-Hall, Inc.

Kean, J. W., McCoy, S. W., Tucker, G. E., Staley, D. M., and Coe, J. A. (2013). Runoff-generated debris flows: Observations and modeling of surge initiation, magnitude, and frequency. J. Geophys. Res. Earth Surf. 118, 2190-2207. doi: 10.1002/jgrf.20148

Lancaster, S. T., Hayes, S. K., and Grant, G. E. (2003). Effects of wood on debris flow runout in small mountain watersheds. Water Resour. Res. 39, 1168. doi: 10.1029/2001WR001227

Lavigne, F., and Suwa, H. (2004). Contrasts between debris flows, hyperconcentrated flows and stream flows at a channel of Mount Semeru, East Java, Indonesia. Geomorphology 61, 41-58. doi: 10.1016/j.geomorph.2003.11.005

Lee, S., and Pradhan, B. (2007). Landslide hazard mapping at Selangor, Malaysia using frequency ratio and logistic regression models. Landslides 4, 33-41. doi: 10.1007/s10346-006-0047-y

Lin, C. W., Wu, M. C., and Shieh, C. L. (2000). "Influence of geology on debrisflows: Examples from Hsin-Yi, Nantou County, Taiwan," in Debris Flow Hazard Mitigation: Mechanics, Prediction and Assessment, Proceedings of the Second International Conference on Debris-Flow, eds Wieczorek and Naeser (Taiwan; Rotterdam: Balkema), 169-176.

Lin, P. S., Lin, J. Y., Huang, J. C., and Yang, M. D. (2002). Assessing debris-flow hazard in a watershed in Taiwan. Eng. Geol. 66, 295-313. doi: 10.1016/s00137952(02)00105-9

Lu, G. Y., Chiu, L. S., and Wong, D. W. (2007). Vulnerability assessment of rainfallinduced debris flows in Taiwan. Nat. Hazards 43, 223-244. doi: 10.1007/s11069006-9105-y

Maleta, J. P., Laigleb, D., Remaitrea, A., and Maquairea, O. (2005). Triggering conditions and mobility of debris flows associated to complex earthflows. Geomorphology 66, 215-235. doi: 10.1016/j.geomorph.2004.09.014

Marinos, P., Hoek, E., and Marinos, V. (2004a). Variability of the Engineering properties of rock masses quantified by the Geological Strength Index. The case of Ophiolites with special emphasis on tunneling. Bull. Eng. Geol. Environ. 65, 129-142. doi: 10.1007/s10064-005-0018-x

Marinos, P., Marinos, V., and Hoek, E. (2004b). "Geological Streength Index, GSI: Applications, recommendations, limitations and alteration fields commensurately with the rock type. Bull. of the Geolo.Society of Greece vol XXXVI," in Proc. of the 10th Intern.Congress (Thessaloniki).

Marinos, V., Marinos, P., and Hoek, E. (2005). The geological strength index: applications and limitations. Bull. Eng. Geol. Environ. 64, 55-65. doi: 10.1007/s10064-004-0270-5

Marra, F., Nikolopoulos, E. I., Creutin, J. D., and Borga, M. (in press). Space-time organization of debris flows-triggering rainfall and its effect on the identification of the rainfall threshold relationship. J. Hydrol. doi: 10.1016/j.jhydrol.2015.10.010

Melton, M. A. (1957). An analysis of the Relation Among Elements of Climate, Surface Properties and Geomorphology, Tech Rep11. Office of Nav Res Dept Geol Columbia Univ.

Montacchini, F., Caramiello-Lomagno, R., Forneris, G., and Piervittori, R. (1982). Carta della vegetazione della Valle di Susa ed evidenziazione dellinflusso antropico. Collana del programma finalizzato "Promozione della qualità dell'ambiente" Consiglio Nazionale delle Ricerche, Torino, pp. 114.

Moscariello, A., Marchi, L., Maraga, F., and Mortara, G. (2002). Alluvial fans in the Alps: sedimentary facies and processes. Spec. Publs. Int. Ass. Sediment. 32, $141-166$.

Ohlmacher, G. C., and Davis, J. C. (2003). Using multiple logistic regression and GIS technology to predict landslide hazard in northeast Kansas USA. Eng. Geol. 69, 331-343. doi: 10.1016/s0013-7952(03)00069-3

Palacios, D., Parrilla, G., and Zamorano, J. J. (1999). Paraglacial and postglacial debris flows on a Little Ice Age terminal moraine: JAMAPA Glacier, Pico de Orizaba (Mexico). Geomorphology 28, 95-118. doi: 10.1016/S0169555X(98)00098-1

Perosino, G. C., and Zazzara, P. (2006). “Elementi climatici del Piemonte," in C.R.E.S.T. - Centro Ricerche in Ecologia e Scienze del Territorio (Torino), 17.

Pierson, T. C., and Costa, J. E. (1987). A rheologic classification of subaerial sediment-water flows. Geol. Soc. Am. Rev. Eng. Geol. 7, 1-12.

Polino, R., Dela Pierre, F., Fioraso, G., Giardino, M., and Gattiglio, M. (2002). Foglio 132-152-153 “Bardonecchia” Carta Geologica d'Italia. scala 1:50000. Servizio Geologico d'Italia.

Ranjan, K. D., Shuichi, H., Atsuko, N., Minoru, Y., Takuro, M., and Katsuhiro, N. (2004). GIS based weights-of-evidence modeling of rainfall-induced landslides in small catchments for landslide susceptibility mapping. Environ. Geol. 54, 311-324. doi: 10.1007/s00254-007-0818-3

Reid, M. E., Brien, D. L., LaHusen, R. G., Roering, J. J., de la Fuente, J., and Ellen, S. D. (2003). “Debris-flow initiation from large, slow-moving landslides," in Debris-Flow Hazard Mitigation: Mechanics, Prediction, and Assessment, eds Rickenmann and Chen (Rotterdam : Millpress), 155-166.

Santi, P. M., deWolfe, V. G., Higgins, J. D., Cannon, S. H., and Gartner, J. E. (2008). Sources of debris flow material in burned areas. Geomorphology 96, 310-321. doi: 10.1016/j.geomorph.2007.02.022

Sassa, K. (1985). "The mechanism of debris flow," in Proceedings of XI International Conference on Soil Mechanics and Foundation Engineering 1985 (San Francisco, CA), 1173-1176.

Schmidt, K. M., Roering, J. J., Stock, J. D., Dietrich, W. E., Montgomery, D. R., and Schaub, T. (2001). The variability of root cohesion as an influence on shallow landslide susceptibility in the Oregon Coast Range. Can. Geotechnical J. 35, 995-1024. doi: 10.1139/t01-031

Sekhar, L. K., van Westen, C., Lakhera, R. C., van Beek, L. P. H., Sankar, G., Alkema, D., et al. (2006). "Effect of vegetation on debris flow initiation: conceptualization and parameterization of a dynamic model for debris flow initiation in Tikovil river basin, Kerala, India, using PCRASTER ${ }^{\circledR}$, , in 2nd International Symposium on Geo-information for Disaster Management (Gi4DM) - Remote Sensing and GIS Techniques for Monitoring and Prediction of Disasters (Goa).

Shakesby, R. A., and Doerr, S. H. (2006). Wildfire as a hydrological and geomorphological agent. Earth Sci. Rev. 74, 269-307. doi: 10.1016/j.earscirev.2005.10.006

Stoffel, M., Bollschweiler, M., and Beniston, M. (2011). Rainfall characteristics for periglacial debris flows in the Swiss Alps: past incidences-potential future evolutions. Climatic Change 105, 263-280. doi: 10.1007/s10584-0110036-6

Stoffel, M., Tiranti, D., and Huggel, C. (2014). Climate change impacts on mass movements-case studies from the European Alps. Sci. Total Environ. 493, 1255-1266. doi: 10.1016/j.scitotenv.2014.02.102 
Styczen, M. E., and Morgan, R. P. C. (1995). "Engineering properties of vegetation," in Slope Stabilization and Erosion Control: A Bioengineering Approach. E and FN, eds R. P. C. Morgan and R. J. Rickson. (London: Spon), 5-58.

Tinker, D. B., and Knight, D. H. (2000). Coarse woody debris following fire and logging in wyoming lodgepole pine forests. Ecosystems 3, 472-483. doi: $10.1007 / \mathrm{s} 100210000041$

Tiranti, D., Bonetto, S., and Mandrone, G. (2008). Quantitative basin characterization to refine debris-flow triggering criteria and processes: an example from the Italian Western Alps. Landslides 5, 45-57. doi: 10.1007/s10346-007-0101-4

Tiranti, D., Cremonini, R., Marco, F., Gaeta, A. R., and Barbero, S. (2014). The DEFENSE (DEbris Flows triggEred by storms - Nowcasting SystEm): an early warning system for torrential processes by radar storm tracking using a Geographic Information System (GIS). Comput. Geosci. 70, 96-109. doi: 10.1016/j.cageo.2014.05.004

Tiranti, D., and Deangeli, C. (2015). Modeling of debris flow depositional patterns according to the catchment and sediment source area characteristics. Front. Earth Sci. 3:8. doi: 10.3389/feart.2015.00008

Tiranti, D., and Rabuffetti, D. (2010). Estimation of rainfall thresholds triggering shallow landslides for an operational warning system implementation. Landslides 7, 471-481. doi: 10.1007/s10346-010-0198-8

Tropeano, D., Govi, M., Mortara, G., Turitto, O., Sorzana, P., Negrini, G., et al. (1999). Eventi alluvionali e frane nell'Italia Settentrionale. Periodo 1975-1981. GNDCI.

Tropeano, D., Luino, F., and Turconi, L. (2006). Eventi Di Piena e Frana in Italia Settentrionale nel Periodo 2002-2004. CNR-IRPI/GNDCI. Pubbl.

Tropeano, D., and Turconi, L. (1999). Valutazione del potenziale detritico in piccoli bacini alpini delle Alpi Occidentali e Centrali. CNR-IRPI/GNDCI. Pubbl.

Tropeano, D., Turconi, L. (2004) Using historical documents for landslides, debris flow and stream flood prevention. Applications in Northern Italy (2004). Nat. Hazards 31, 663-679. doi: 10.1023/B:NHAZ.0000024897.71471.f2
Tunusluoglu, M. C., Gokceoglu, C., Nefeslioglu, H. A., and Sonmez, H. (2008). Extraction of potential debris source areas by logistic regression technique: a case study from Barla, Besparmak and Kapi mountains (NW Taurids, Turkey). Environ. Geol. 54, 9-22. doi: 10.1007/s00254-0070788-5

Turconi, L., Nigrelli, G., and Conte, R. (2014). Historical datum as a basis for a new GIS application to support civil protection services in NW italy. Comput. Geosci. 66, 13-19. doi: 10.1016/j.cageo.2013.12.008

van Beek, L. P. H., and van Asch, T. W. J. (2004). Regional Assessment of the effects of land-use change on landslide hazard by means of physically based modelling. Nat. Hazards 30, 289-304. doi: 10.1023/B:NHAZ.0000020267.39691.39

Wieczorek, G. F., and Glade, T. (2005). "Climatic factors influencing occurrence of debris flow," in Debris Flow Hazard and Related Phenomena, eds Jacob and Hungr (Berlin; Heidelberg: Springer), 325-352.

Wilford, D. J., Sakals, M. E., Innes, J. L., Sidle, R. C., and Bergerud, W. A. (2004). Recognition of debris flow, debris flood and flood hazard through watershed morphometrics. Landslides 1, 61-66. doi: 10.1007/s10346-003-0002-0

Zelt, R. B., and Wohl, E. E. (2004). Channel and woody debris characteristics in adjacent burned and unburned watersheds a decade after wildfire, Park County, Wyoming. Geomorphology 57, 217-233. doi: 10.1016/S0169-555X(03)00104-1

Conflict of Interest Statement: The authors declare that the research was conducted in the absence of any commercial or financial relationships that could be construed as a potential conflict of interest.

Copyright (C) 2016 Tiranti, Cremonini, Asprea and Marco. This is an open-access article distributed under the terms of the Creative Commons Attribution License (CC $B Y)$. The use, distribution or reproduction in other forums is permitted, provided the original author(s) or licensor are credited and that the original publication in this journal is cited, in accordance with accepted academic practice. No use, distribution or reproduction is permitted which does not comply with these terms. 